\title{
CYTOTOXIC EVALUATION OF ANTICANCER FOLATE DECORATED CARBOPLATIN LOADED ALBUMIN NANOPARTICLES USING FOLATE RECEPTOR OVEREXPRESSING CELL LINES
}

\author{
Hosam A. Abdelwahab ${ }^{2}$, Mervat E. Asker ${ }^{1}$, Nahla S. Kotb ${ }^{2}$, Hoda E. Mohamed ${ }^{1}$ \\ ${ }^{1}$ Department of Biochemistry, Faculty of Pharmacy, Zagazig University, Egypt, \\ ${ }^{2}$ Biologics and innovators sector, Egyptian drug authority, Egypt
}

Corresponding author: E-mail: hosamabdelhay90@gmail.com

\begin{abstract}
Lack of selectivity, toxic side effects and multidrug resistance represent major limitations for chemotherapy treatment against cancer. The non-specific targeting of the chemotherapeutic agents leads to the rapid damage of normal cells. This could be significantly reduced through folate mediated nano-therapeutics which aimed to target cancerous cells. In this study, a folate decorated carboplatin loaded albumin nanoparticles was prepared aiming to successful active targeting of folate receptor overexpressing cancer cells which inconsequence decrease side effects and increase efficacy of carboplatin. The formulation was prepared using desolvation technique, glutaraldehyde as a cross linker, bovine serum albumin as a nanocarrier and folic acid as a targeting ligand. Physical characterization of the formulation was carried out as per of particle size, zeta potential and poly dispersity index (PDI). Results showed $(267.29 \mathrm{~nm})$ particles with $(-30.4 \mathrm{mV})$ potential and (0.069) PDI which confirmed a successful preparation of the formulation. For evaluation of the cytotoxic effect of the suggested formulation against the free form of the Carboplatin, an MTT cytotoxic assay was performed on folate receptor overexpressing cell lines (Caco2, PC3) a human colon cancer cell line and a prostate cancer cell line respectively. Results revealed higher significant efficacy represented by lower the half maximal Inhibitory concentration (IC50) values which gives a new hope for using carboplatin in a more effective and safe way in treatment after further clinical investigations.
\end{abstract}

Keywords: Carpoplatin, nanoparticles, folate decorated, albumin, cancer, cytotoxic effect 


\section{Introduction}

Carboplatin is a platinum-based drug approved by FDA in 1980 and synthesized as an analogue of Cisplatin. It is widely used in combination with other drugs in treatment of a variety of cancers such as testis, ovary, head, neck, and small cell lung cancer (Sousa, Wlodarczyk et al. 2014). Inside the cell after being internalized they are activated to nucleophilic form that can bind to peptides and DNA exerting its cytotoxic effect by preventing DNA replication process. Many side effects were recorded for carboplatin including neurotoxicity, severe cumulative myelosuppression, renal toxicity and ototoxicity that are commonly caused by platinum-based chemo-therapy (Oun, Moussa et al. 2018).

Another constraint of utilizing carboplatin was building up a multidrug resistance by various mechanisms (Oun, Moussa et al. 2018). Likewise, excessive hypersensitivity against carboplatin is another issue experienced by around 15-20\% of ladies with ovarian growth. They experienced different degrees of allergic reactions tingling, rash, chest snugness, emesis, circulatory strain changes and facial swelling. The beginning of the carboplatin-related HSR is additionally exceptionally factor, happening either when the implantation begins or after it is finished (Fotopoulou 2014).

Nanoparticles as carriers for cytotoxic agents represent a great role for overcoming challenges and limitations against chemotherapeutic drugs. Including carboplatin inside Nano sized polymers have been tested using Alginate polymer complexed with chitosan and showed good encapsulation and stability results (Nanjwade, Singh et al. 2010).In 2016 a study of formulating carboplatin in PLGA nanoparticles was suggested to enhance the targeting effect of the drug in brain tumors (Jose, Juna et al. 2016).Chitosan nanoparticles prepared by ionic interaction introduced a promising drug delivery system for carboplatin in treatment of breast cancer (Khan, Zafaryab et al. 2017).

Human serum albumin (HAS) and bovine serum albumin (BSA) have many physicochemical advantages which give them the chance to be a good a perfect candidate in drug delivery systems (Zhao, Zhao et al. 2010). Stability against temperature and $\mathrm{pH}$, particular take-up in tumor and excited tissue, prepared accessibility, biodegradability, and absence of toxicity are examples of these recommending properties (Jahanshahi and Babaei 2008, Elzoghby, Samy et al. 2012).

Active targeting of chemotherapy aims to make new designs of the drug molecules to be delivered to diseased tissues in higher concentrations than healthy tissues, thus increases efficacy and decreases side effects to a great extent. The drug molecule - either directly or after incorporation in a carrying system - to is conjugated to a ligand such as folic acid that can recognize the diseased tissue (Bertrand, Wu et al. 2014). It has been reported that folic acid was used as a promising targeting ligand for therapeutic or diagnostic nanoparticles in the few past years of research (Vasir and Labhasetwar 2005, Pan and Feng 2008, Li, Yang et al. 2014, Gazzano, Rolando et al. 2018). 
Folate receptor specifically the isoform alpha is found to be overexpressed on the surface of many tumors and it is a high affinity membrane bound protein that controls uptake of folic acid to inside the cell (Zhao, Zhao et al. 2010, Khan, Zafaryab et al. 2017).

In this study a BSA nanoparticles loading carboplatin was prepared then decorated with folic acid as a targeting delivery system for cancer treatment. A full physical characterization regarding size, zeta Potential, entrapment and loading efficacy, folic acid conjugation has been carried out and proved successful preparation of the formulation Carb-BSA-FA. The system was then tested for cell cytotoxicity on two folate receptors overexpression cell lines Caco 2 human colon carcinoma cell line \& PC3 human prostate cancer cell line.

\section{Materials and Methods}

\subsection{Subjects}

Cell lines are provided from (Vacsera tissue culture unit, Egypt)

\subsection{Chemicals, Reagents, and Standards}

Folic acid, phosphate buffer saline and N-hydroxy succinic acid, neutral red dyes obtained from (Bio Basic, Canada). N, N Di cyclo carbodimide and Triethyl amine obtained from (Arcos, Germany). Bovine serum albumin fraction V was provided by (LSP, USA). Fetal Bovine serum, trypsin, Antibiotic sterile solution, RPMI cell culture medium and Tryban blue dye solution obtained from (Lonza, Switzerland). The Carboplatin was provided as solution for injection $(10 \mathrm{mg} / \mathrm{ml})$ and 3-(4,5- Dimethylthiazole-2-yl)-2,5diphenyltetrazolium (MTT) dyes purchased from (Sigma Aldrich, USA). Ethanol, glacial acetic acid, glutaraldehyde, acetonitrile and dimethyl sulfoxide was used as analytic reagents were purchased as analytic agents and were of high-performance liquid chromatography grade from (Thermoficher scientific, UK). The water used was pretreated with the Milli-Q plus system (Merck millipore, USA).

\subsection{Instruments}

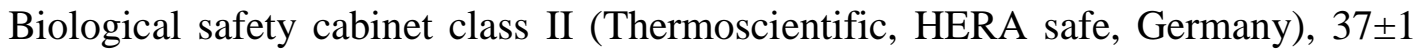
${ }^{\circ} \mathrm{C} \mathrm{CO}_{2}$ Incubator (Thermoscientific, Germany), Inverted microscope (Olympus, USA), and a microplate ELISA multimode reader with Magellan data analysis software (Tecan, Austria) were used in tissue culture measurements. An Aglient-1200 HPLC (Aglient Technologies, Germany) equipped with a photo diode array (PDA) detector, auto-sampler and temperature-controlled column compartment was used for chromatographic separations. Malvern zetasizer nano ZS (Malvern instruments Ltd., UK) fitted with $4 \mathrm{~mW}$ helim/neon laser at $633 \mathrm{~nm}$ wavelength along with non-invasive back-scatter optics at a detection angle of $173^{\circ}$ was used for Dynamic light scattering (DLS) analysis. 


\subsection{Experimental}

\subsubsection{Preparation of Folate decorated Carboplatin BSA nanoparticles} First Folic acid is activated to form an ester with NHS by the method described by Lee and Low (Lee \& Low, 1994).

For preparation of BSA nanoparticles we followed the desolvation technique (Langer, Balthasar et al. 2003).

To prepare carboplatin encapsulating BSA nanoparticle the same procedure described above is used except dissolving the BSA in $2 \mathrm{ml}(2 \mathrm{mg} / \mathrm{ml})$ carboplatin solution in water instead of using distilled water as a solvent, the rest of steps till purification are exactly the same. The prepared nanoparticles were vacum dried and stored as powder.

To induce conjugation between albumin Nano particles and the activated folate NHS ester the following procedure is followed (Zhao, Zhao et al. 2010) $5 \mathrm{mg} / \mathrm{ml}$ solution of NHS folate in Carbonate bicarbonate buffer (PH 10) is added to the nanoparticles suspension on stirring and kept overnight, then the conjugated nanoparticles are purified and dried as previously described.

\subsubsection{Characterization of nanoparticles.}

\subsubsection{Particle size and zeta potential}

Particle size and zetapotentail of the prepared three groups : a) FA-BSA Nps , b) Carb-BSA-FA \& c) Carb-BSA Nps were measured by the Dynamic light scattering technique (DLS) using (Nanotrac Wave II analyzer) after suitably diluting the sample (1:100) in purified water (MilliQ water system) (Pieper, Onafuye et al. 2019).

\subsubsection{NHS Folate preparation efficiency}

Both Folic acid powder and NHS-Folate prepared powder were scanned using UV spectrophotometer in the range of 250 to $400 \mathrm{~nm}$ to be tested for matching (Zhao, Zhao et al. 2010).

\subsubsection{Drug Entrapment Efficacy}

Carboplatin concentration was quantified using high performance liquid chromatography (HPLC) method as previously described (Mittal, Chitkara et al. 2007). 2.4.3 In vitro cell cytotoxicity assay

To evaluate the cytotoxicity of the formulations, Caco2 and PC3cell lines were used 
The cell lines were grown and maintained using RPMI growth media containing $10 \% \mathrm{FBS}$ and $1 \%$ antibiotic sterile solution in $37{ }^{\circ} \mathrm{C}$ in $5 \% \mathrm{CO}_{2}$ incubator and detached then sub cultured when required using Trypsin solution with EDTA (Absher 1973, Riss, Moravec et al. 2016).

\subsubsection{MTT Assay}

Cells were seeded in 96 well plates when reaches confluence in culture flasks to be a density of 2-3x $10^{4}$ (Cells/well) using 10\% growth RPMI medium as described earlier (Absher 1973, Riss, Moravec et al. 2016) then left to attach overnight in the same mentioned conditions of incubation. The next day of incubation the media was discarded and replaced with serial concentrations of the drug (Free carboplatin, Carb-BSA NPs \& Carb-BSA-FA) diluted with fresh medium keeping wells without any drug added as control group then the plate is retuned back to incubation for $48 \mathrm{hrs}$. After the end of incubation period between the cells and the media or the media contacting drug, the supernatant above the cells in the 96 well cell culture plate was discarded and $20 \mu \mathrm{l}$ of $(5 \mathrm{mg} / \mathrm{ml})$ MTT solution in PBS is added to each well. After 2-4 hrs. of incubation in $37^{\circ} \mathrm{C}$ MTT is discarded and $150 \mu \mathrm{l}$ of DMSO is add to each well then incubated again for 30 min till complete dissolving of formazan crystals. Then absorbance is measured on $570 \mathrm{~nm}$ UV ELISA reader and viability against concentration was plotted to calculate IC50 of carboplatin in different forms for each cell line individually using (Prism Graph Pad 7) software.

\subsection{Statistical analysis}

To confirm the results and to ensure significance of the cytotoxicity assay for MTT assay on $\mathrm{CaCo} 2 \& \mathrm{PC} 3$ cell lines, the $\mathrm{P}$ value was calculated using unpaired t-student test and the difference was considered statistically significant at $\mathrm{P}<0.05$. Moreover, IC50 was undertaken and all statistical analysis was performed using Graphpad prism7 software (Graphpad software, La Jolla, CA.USA).

\section{Results and discussion}

\subsection{Characterization of nanoparticles.}

\subsubsection{Particle size and zeta potential}

After physical characterization of the prepared nanoparticles the mean of particle size and zeta potential expressed as standard of deviation of three independent readings are summarized in Table 1. The results showed that the measured particle size was $<500 \mathrm{~nm}$ and zeta potential with a suitability negatively charged which allowed a favorable repulsion between particles producing uniform formulations, also polydespersity index (PI) was found to be (0.069) which is less than 0.2 indicating homogenousity of the prepared nanoparticles suspension as shown in Fig. 1 
All these results were found to be align with previous preparations using the same desolvation technique and were acceptable for delivering the encapsulated drug (Zhao, Zhao et al. 2010, Lombardo, Kiselev et al. 2019).

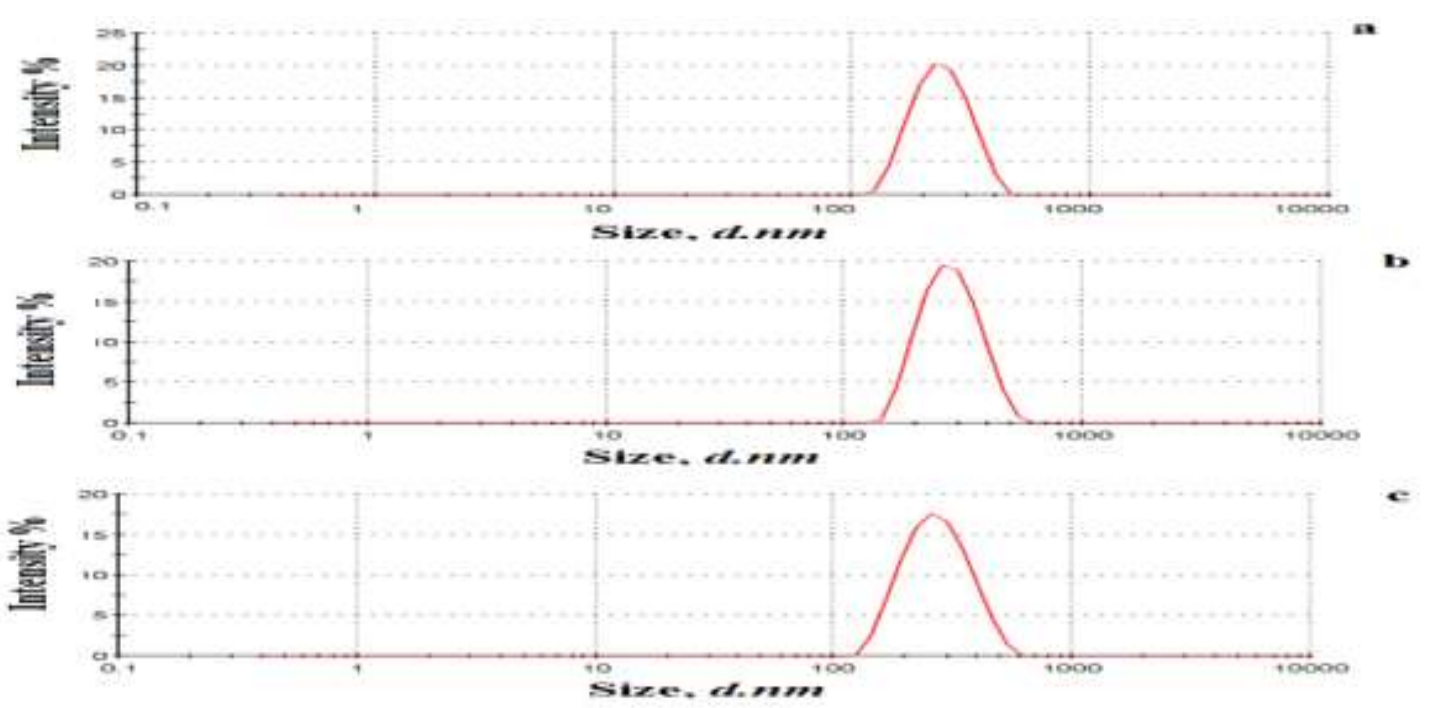

Fig. 1. Intensity size distribution of: (a) Carboplatin, (b) Carb-BSA, (c) Carb-BSA-FA, showing the monomer peak of Carboplatin, Carb-BSA, Carb-BSA-FA respectively.

Table 1. Summary of particle size, zeta potential and PDI of the studied formulations.

\begin{tabular}{llll}
\hline & Particle size $(\mathbf{n m})$ & PI & Zeta potential $(\mathbf{m V})$ \\
Carb-BSA-FA & 267.29 & 0.069 & -30.4 \\
Carb-BSA & 244.1 & 0.125 & -28.9 \\
BSA-FA & 219.05 & 0.045 & -26.75 \\
\hline
\end{tabular}

\subsubsection{Folic acid conjugation efficiency}

Successful formulation of NHS-Folate was confirmed by scanning $(5 \mathrm{mg} / \mathrm{ml})$ solution samples of both folic acid and NHS-Folate using UV spectrometer within range (250-400 $\mathrm{nm}$ ) and both showed maximum absorption peak on (366 nm) (Liang, Li et al. 2018)(Liang, Li et al. 2018) matched spectrum of Folic acid, NHS-Folate and FA-Naked Nano particles are shown in Fig. 2. 


\begin{tabular}{lllll}
\hline & $\begin{array}{l}\text { Carboplatin } \\
\text { concentration } \\
\text { supernatant }(\boldsymbol{\mu g} / \mathbf{m l})\end{array}$ & $\begin{array}{l}\text { Nanoparticle } \\
\text { yield }(\mathbf{m g})\end{array}$ & DEE $(\%)$ & DLE $(\boldsymbol{\mu g} / \mathbf{m g})$ \\
Carb-BSA & 72.8 & 85 & 82.7 & 38.9 \\
$\begin{array}{l}\text { Carb-BSA- } \\
\text { FA }\end{array}$ & 82 & 90 & 80.5 & 35.7
\end{tabular}
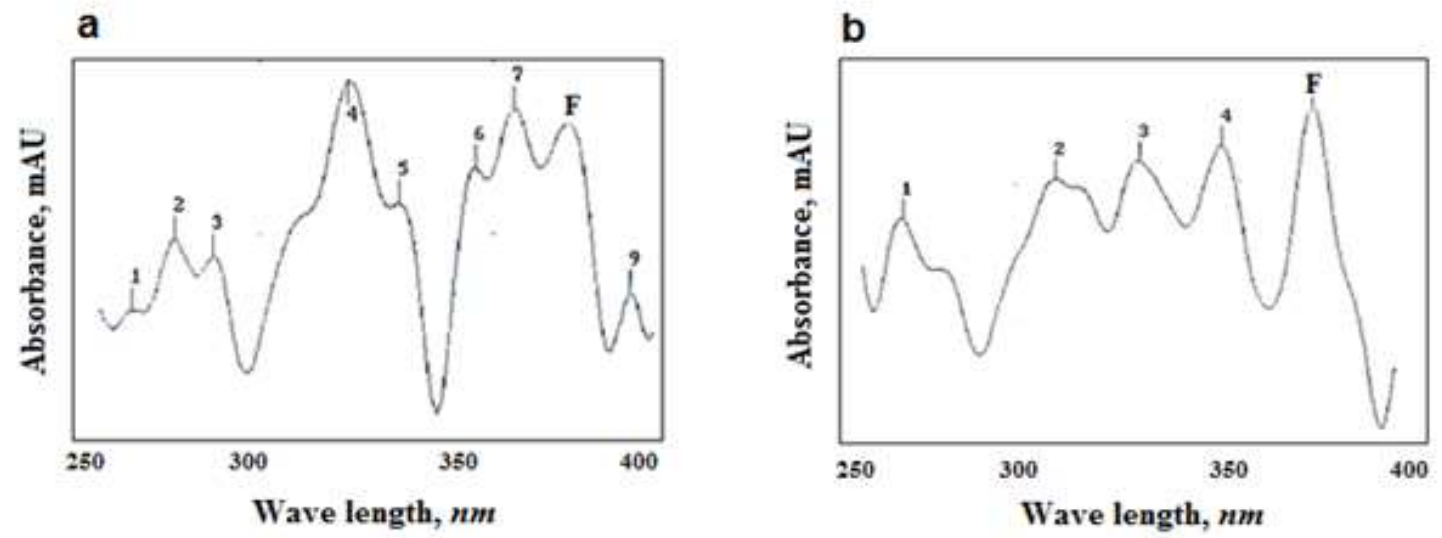

Fig. 2. UV spectrum of (A) NHS Folate (B) Folic Acid standard solution showing peak F: A matching peak of $366 \mathrm{~nm}$.

\subsubsection{Drug Entrapment Efficacy}

RP-HPLC system was used to determine the Drug loading efficacy and Drug entrapment efficacy of the formulations. First a standard calibration curve of carboplatin was done using concentration range $(5-1000 \mu \mathrm{g} / \mathrm{ml})$. Then the supernatant collected from the purification of the formulation by centrifugation was assayed for carboplatin by the same system. The concentration of drug in supernatant was determine by measuring its area under peak as a mean of three independent injections of the sample then using the standard curve to define the corresponding concentration. (Fig. 3) 

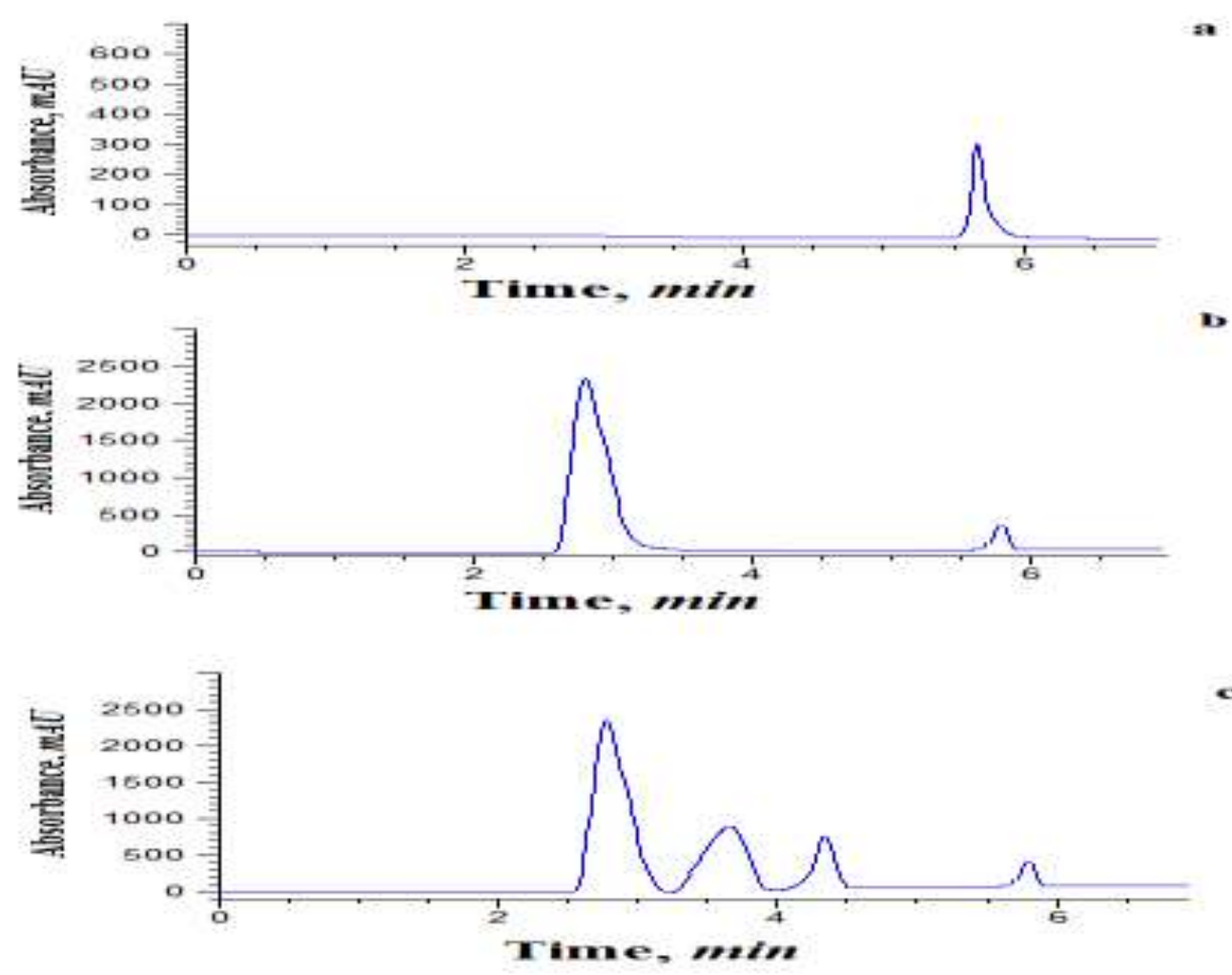

Fig. 3. RP-HPLC analysis results of: (a) Carboplatin drug standard, (b) Carb-BSA (c) CarbBSA-FA, showing the monomer peak of 5FU. Analysis was carried out using Zobrax 300C18 column, mobile phase consists of distilled water and acetonitrile in ratio 70:30\% v/v, flow rate of $1 \mathrm{~mL} / \mathrm{min}$, and detection wavelength of $227.0 \mathrm{~nm}$.

Knowing the supernatant concentration of the drug and the nanoparticles yield (weight of nanoparticles after drying or total protein content before drying) DEE and DLE are calculated and summarized in Table 2.

\subsection{In vitro cytotoxicity}

Table 2. Summary of the supernatant concentrations and the entrapped drug percentage in the studied formulations.

\begin{tabular}{|l|l|l|l|l|}
\hline & $\begin{array}{l}\text { Carboplatin } \\
\text { concentration } \\
\text { in supernatant } \\
(\mu \mathrm{g} / \mathrm{ml})\end{array}$ & $\begin{array}{l}\text { Nanoparticle } \\
\text { yield }(\mathrm{mg})\end{array}$ & DEE $(\%)$ & DLE $(\mu \mathrm{g} / \mathrm{mg})$ \\
\hline Carb-BSA & 72.8 & 85 & 82.7 & 38.9 \\
\hline Carb-BSA-FA & 82 & 90 & 80.5 & 35.7 \\
\hline
\end{tabular}




\subsubsection{MTT assay}

\subsubsection{MTT assay on Caco2 cell line}

MTT depends on the activity of the viable cell mitochondrial dehydrogenase enzyme to convert the yellow MTT dye to a violet formazan crystals that can be dissolved and assayed for color intensity (Borenfreund, Babich et al. 1988). when carboplatin is encapsulated in nanoparticles and then decorated with folic acid, a significant inhibitory effect could be seen when comparing the same concentration of carboplatin free drug (Fig 4a). The folate decorated form showed the best inhibitory effect with the lower IC50 (89.1 $\mu \mathrm{g} / \mathrm{ml})$ while IC50 of the free drug was $(192.8 \mu \mathrm{g} / \mathrm{ml})$ This significance can be statistically noticed when using the unpaired t-test that shows a significant difference between Free Drug and Carb-BSA-FA with adjusted $\mathrm{P}$ value $<0.05$. These results give a promising indicator of the folate decorated bovine serum albumin nanoparticles as an effective carrier for targeting the carboplatin into cancer cells through its uptake by the folate receptor which is over expressed on the surface of the majority of solid tumor more than normal cells that minimally express the folate receptor target.
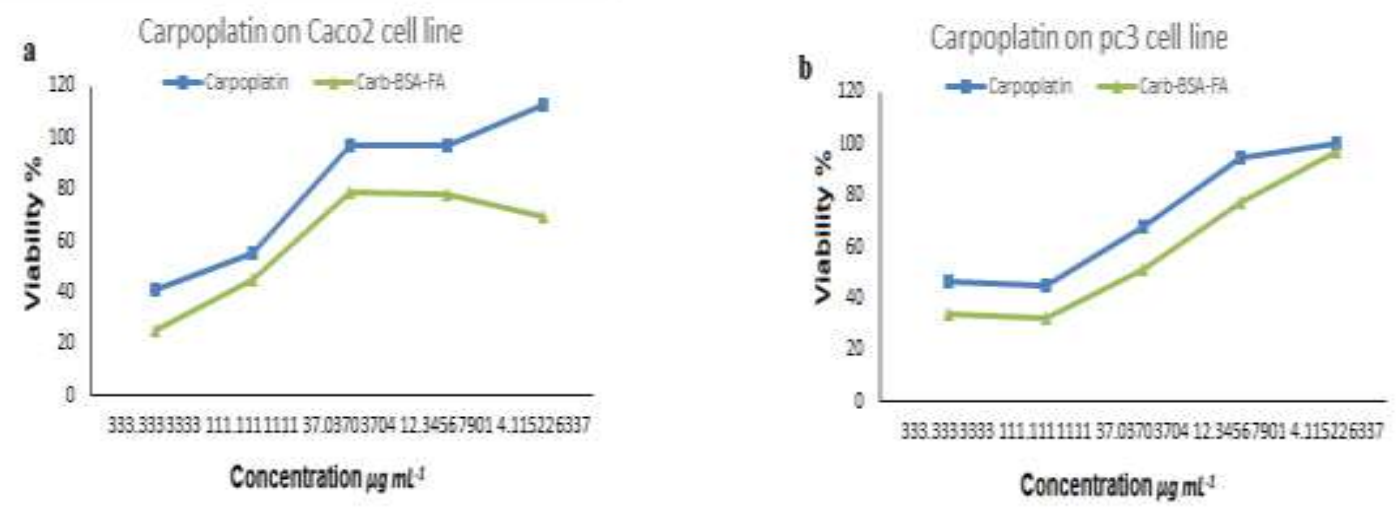

Fig. 4. Results of MTT assay: a) Carboplatin, Carb-BSA-FA on caco2 cell line b) Carboplatin, Carb-BSA-FA on PC3 cell line, showing a significant inhibitory effect of the folic decorated form of the nanoparticles encapsulated formulations Carb-BSA-FA.

\subsubsection{MTT assay on PC3 cell line}

The results of MTT assay was further verified for another folate receptor over expressing cell line (PC3). The folate decorated form of the drug successfully showed a significantly higher inhibitory effect over increasing the concentration more than that shown by the corresponding concentrations of the free form of the drug (Fig. $\mathbf{4 b}$ ). This significance could be statistically noticed when using unpaired t-student test model with adjusted $\mathrm{P}$ value $(<0.05)$. In addition, the IC50 of Folic acid decorated form of carpoplatin 
showed a lower value $(36.2 \mu \mathrm{g} / \mathrm{ml})$ in comparison with the free form of the drug $(102.8$ $\mu \mathrm{g} / \mathrm{ml})$.

\section{Conclusion:}

An increasingly effective drug targeted delivery system is a leading upcoming direction in chemotherapeutic treatment field. Thus, a folic acid decorated carboplatin loading BSA nanoparticles formulation has been prepared and characterized and tested for cytotoxic effect on different folate receptor overexpressing cell lines in an attempt to increase selectivity and efficacy and decrease side effects of carboplatin cytotoxic agent. Results of the physical characterization of Carb-BSA-FA revealed homogenous preparation regarding size, zeta potential, PDI and folate conjugation, cytotoxic evaluation was done using MTT viability assay on two different cell lines (Caco2, PC3). Results revealed significant difference and lower IC50 when the formulation tested against the free form of the drug. It was highly clear that this study recommends that Carb-BSA-FA gives new hopes in fight against cancer with high efficacy and selectivity.

\section{References:}

Absher, M. (1973). Hemocytometer counting. Tissue culture, Elsevier: 395-397.

Bertrand, N., J. Wu, X. Xu, N. Kamaly and O. C. Farokhzad (2014). "Cancer nanotechnology: the impact of passive and active targeting in the era of modern cancer biology." Advanced drug delivery reviews 66: 2-25.

Borenfreund, E., H. Babich and N. Martin-Alguacil (1988). "Comparisons of two in vitro cytotoxicity assays - the neutral red (NR) and tetrazolium MTT tests." Toxicology in vitro 2(1): 1-6.

Elzoghby, A. O., W. M. Samy and N. A. Elgindy (2012). "Albumin-based nanoparticles as potential controlled release drug delivery systems." Journal of controlled release 157(2): 168-182.

Fotopoulou, C. (2014). "Limitations to the use of carboplatin-based therapy in advanced ovarian cancer." European Journal of Cancer Supplements 12(2): 13-16.

Gazzano, E., B. Rolando, K. Chegaev, I. C. Salaroglio, J. Kopecka, I. Pedrini, S. Saponara, M. Sorge, I. Buondonno and B. Stella (2018). "Folate-targeted liposomal nitrooxy-doxorubicin: An effective tool against P-glycoprotein-positive and folate receptor-positive tumors." Journal of controlled release 270: 37-52.

Jahanshahi, M. and Z. Babaei (2008). "Protein nanoparticle: a unique system as drug delivery vehicles." African Journal of Biotechnology 7(25). 
Jose, S., B. Juna, T. Cinu, H. Jyoti and N. Aleykutty (2016). "Carboplatin loaded Surface modified PLGA nanoparticles: Optimization, characterization, and in vivo brain targeting studies." Colloids and Surfaces B: Biointerfaces 142: 307-314.

Khan, M. A., M. Zafaryab, S. H. Mehdi, J. Quadri and M. M. A. Rizvi (2017). "Characterization and carboplatin loaded chitosan nanoparticles for the chemotherapy against breast cancer in vitro studies." International journal of biological macromolecules 97: 115-122.

Langer, K., S. Balthasar, V. Vogel, N. Dinauer, H. Von Briesen and D. Schubert (2003). "Optimization of the preparation process for human serum albumin (HSA) nanoparticles." International journal of pharmaceutics 257(1-2): 169-180.

Li, L., Q. Yang, Z. Zhou, J. Zhong and Y. Huang (2014). "Doxorubicin-loaded, charge reversible, folate modified HPMA copolymer conjugates for active cancer cell targeting." Biomaterials 35(19): 5171-5187.

Liang, J., R. Li, Y. He, C. Ling, Q. Wang, Y. Huang, J. Qin, W. Lu and J. Wang (2018). "A novel tumor-targeting treatment strategy uses energy restriction via codelivery of albendazole and nanosilver." Nano Research 11(9): 4507-4523.

Lombardo, D., M. A. Kiselev and M. T. Caccamo (2019). "Smart nanoparticles for drug delivery application: development of versatile nanocarrier platforms in biotechnology and nanomedicine." Journal of Nanomaterials 2019.

Mittal, A., D. Chitkara and N. Kumar (2007). "HPLC method for the determination of carboplatin and paclitaxel with cremophorEL in an amphiphilic polymer matrix." Journal of chromatography B $\mathbf{8 5 5}(2)$ : 211-219.

Nanjwade, B. K., J. Singh, K. A. Parikh and F. Manvi (2010). "Preparation and evaluation of carboplatin biodegradable polymeric nanoparticles." International journal of pharmaceutics 385(1-2): 176-180.

Oun, R., Y. E. Moussa and N. J. Wheate (2018). "The side effects of platinum-based chemotherapy drugs: a review for chemists." Dalton transactions 47(19): 66456653.

Pan, J. and S.-S. Feng (2008). "Targeted delivery of paclitaxel using folate-decorated poly (lactide)-vitamin E TPGS nanoparticles." Biomaterials 29(17): 2663-2672.

Pieper, S., H. Onafuye, D. Mulac, J. Cinatl Jr, M. N. Wass, M. Michaelis and K. Langer (2019). "Incorporation of doxorubicin in different polymer nanoparticles and their anticancer activity." Beilstein journal of nanotechnology 10(1): 20622072. 
Riss, T. L., R. A. Moravec, A. L. Niles, S. Duellman, H. A. Benink, T. J. Worzella and L. Minor (2016). Cell viability assays. Assay Guidance Manual [Internet], Eli Lilly \& Company and the National Center for Advancing Translational Sciences.

Sousa, G. F. d., S. R. Wlodarczyk and G. Monteiro (2014). "Carboplatin: molecular mechanisms of action associated with chemoresistance." Brazilian Journal of Pharmaceutical Sciences 50(4): 693-701.

Vasir, J. K. and V. Labhasetwar (2005). "Targeted drug delivery in cancer therapy." Technology in cancer research \& treatment 4(4): 363-374.

Zhao, D., X. Zhao, Y. Zu, J. Li, Y. Zhang, R. Jiang and Z. Zhang (2010). "Preparation, characterization, and in vitro targeted delivery of folate-decorated paclitaxelloaded bovine serum albumin nanoparticles." International journal of nanomedicine 5: 669 . 


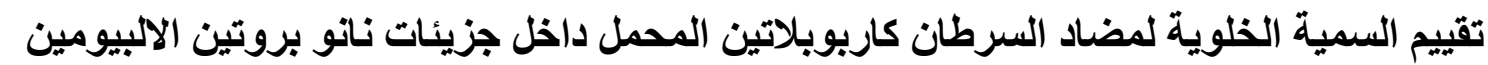

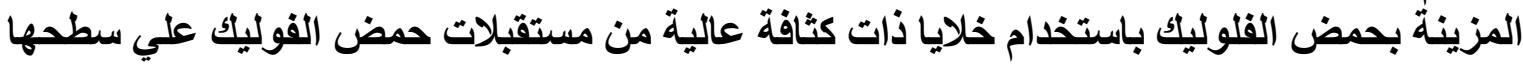

\author{
حسام عبد الوهاب' , ميرفت عسكر' , نهلة قطب '، هلى محمد' \\ 'قطاع المستحضرات الحيوية و المبتكرة - هيئة الدواء المصرية،

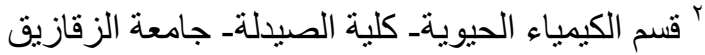 \\ البريد الاكتروني للباحث الرئيسي:gmail.com
}

الملخص العربي

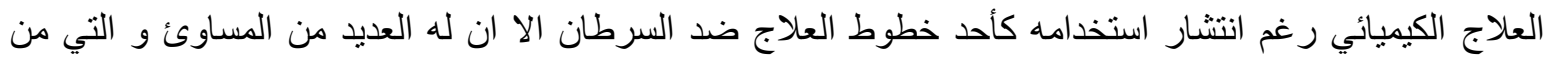

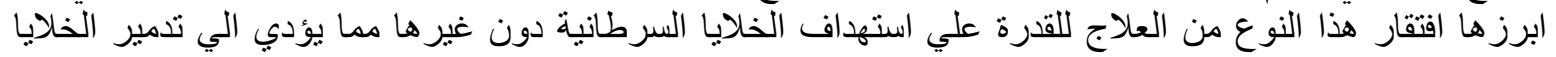

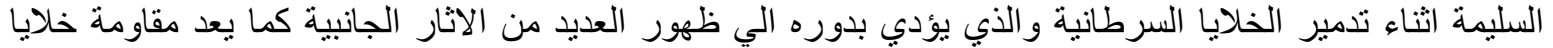
السرطان للادوية هو تحدي اخر في مو اجهة استخدام هذا النوي لنوع من العلاج.

الافتقار الي الاستهداف يمكن التغلب عليه عن طريق تقنية حديثة من احتو اء العلاج الكيميائي داخل جزيئات من النانو

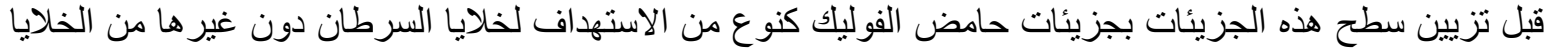

في هذه الدر اسة تم احتو اء مضاد السرطان (كاربوبلاتين) داخل بروتينات النانو المصنعه من بروتين الالبيو البيومين البقري

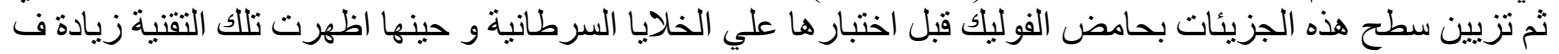

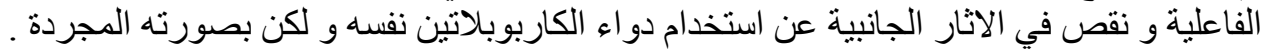

بعد تحضير جزيئات النانو السابق ذكرها تم تحديد خو اصها الفيزيائية و التي من ابرزها حجم الجزيئات و شحنتها و

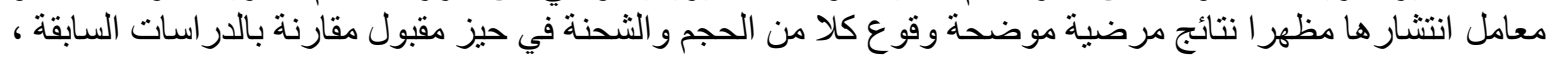
كما اظهر معامل الانتشار عند قياسه تجانس توزيع الجزيئات في حيز ضيق من من فئ الحجوم.

و لتقييم الفاعلية و الاثار الجانبية لمثل هذا الثكل الدوائي تم تقييمه ضد الصورة المجردة من مضاد السرطان (كاربو

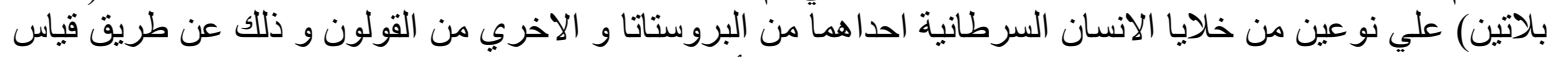

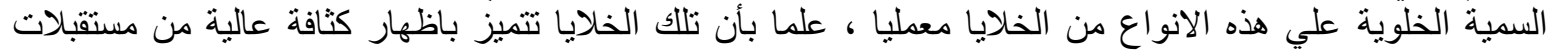

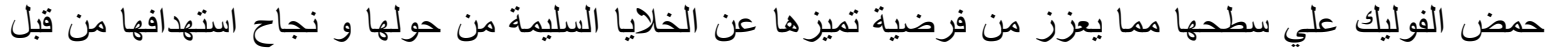

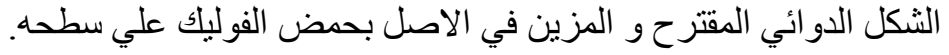

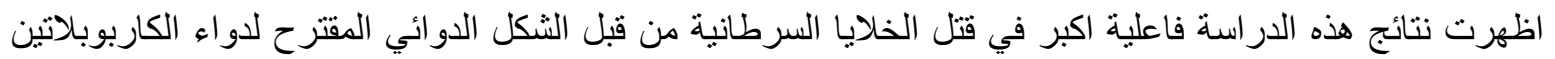

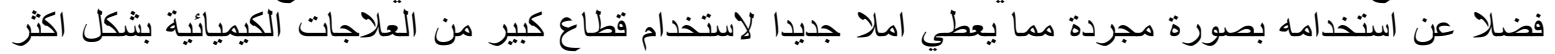
فاعليةو اكثر امانا في علاج السرطان و ذلك بعد الخضوع للمزيد من الاستقصاءات و الدراسات السريرية. كلمات مفتاحية: كاربوبلاتين، جزيئات نانو، مزينة ب حمض الفوليك، البيومين، سرطان، السمية الخلوية 